\title{
Willingness to Pay for Crowdfunding Local Agricultural Climate Solutions
}

\author{
Per Espen Stoknes ${ }^{1, *} \mathbb{C}$, Olav B. Soldal ${ }^{1} \mathbb{C}$, Sissel Hansen ${ }^{2}$, Ingvar Kvande ${ }^{2}$ and Sylvia Weddegjerde Skjelderup ${ }^{3}$ \\ 1 BI Norwegian Business School, 0484 Oslo, Norway; olav.b.soldal@bi.no \\ 2 NORSØK, Norwegian Centre for Organic Agriculture, 6630 Tingvoll, Norway; \\ sissel.hansen@norsok.no (S.H.); ingvar.kvande@norsok.no (I.K.) \\ 3 Fagskolen Kristiania, 0153 Oslo, Norway; sweddegjerde@hotmail.com \\ * Correspondence: per.e.stoknes@bi.no
}

Citation: Stoknes, P.E.; Soldal, O.B.; Hansen, S.; Kvande, I.; Skjelderup, S.W. Willingness to Pay for Crowdfunding Local Agricultural Climate Solutions. Sustainability 2021, 13, 9227. https://doi.org/10.3390/ su13169227

Academic Editors: Dario Siggia and Ashutosh Kolte

Received: 30 June 2021

Accepted: 9 August 2021

Published: 17 August 2021

Publisher's Note: MDPI stays neutral with regard to jurisdictional claims in published maps and institutional affiliations.

Copyright: (c) 2021 by the authors. Licensee MDPI, Basel, Switzerland. This article is an open access article distributed under the terms and conditions of the Creative Commons Attribution (CC BY) license (https:// creativecommons.org/licenses/by/ $4.0 /)$.

\begin{abstract}
The recent rise in climate concern among citizens worldwide is coinciding with a rising interest in agricultural climate solutions. The future scaling-up of these solutions, however, requires more knowledge about the mitigation potential, costs and financing options, including crowdfunding $(\mathrm{CF})$. Our objective is to explore the driving factors behind the public's willingness to pay for crowdfunded climate mitigation projects at the farm level. In this study, four mitigation options from the perspective of farmers were identified: solar panels on the barn roof, biogas from animal manure, drag hoses for improved manure dispersal, and the addition of biochar to soils. The study investigates the optimal characteristics of crowdfunding campaigns to finance such mitigation measures. The most influential factors on the respondents' WTP is neither climate concern nor proximity, but instead the knowledge regarding $\mathrm{CF}$, combined with how comprehensible and salient the suggested measure is. The main implications are that future projects that aim to achieve broad participation in CF campaigns need to communicate well, to improve both public knowledge of the funding mechanism (CF) itself and the comprehensibility and salience of the agricultural measure.
\end{abstract}

Keywords: crowdfunding; agricultural economics; climate change; willingness to pay; carbon offsetting; sustainable agriculture

\section{Introduction}

In this article, we study the Norwegian public's willingness to pay in crowdfunding campaigns to achieve additional climate mitigation measures at the farm level. The purpose is to establish whether such crowdfunding can be an additional source of finance for farmers by enabling the private sector and the public to invest more in local food security and sustainable agriculture. If the response is positive, crowdfunding could be a potential source of "additional capital to existing support schemes that are available to farmers" through the Norwegian government's agricultural subsidy program, rather than to replace it [1]. Earlier studies have established that Norwegians show a strong preference for locally produced and distinctive food [2]. A recent survey further found that $70 \%$ of Norwegians consider it urgent to act on climate change [3], while another survey reported that $70 \%$ of Norwegians consider themselves to have a personal responsibility to act on climate mitigation [4].

Together, such preferences could possibly influence willingness to pay (WTP) a premium for local, climate-friendly food and energy production, particularly if their extra contribution is seen as "earmarked" for climate action [5,6]. Internationally, a number of new crowdfunding platforms have appeared for funding farm-based carbon mitigation and so-called nature-based solutions, such as the Terraton initiative, MoorFutures, Nori or Puro Earth (for details, see www.terraton.indigoag.com, www.moorfutures.de, www.nori.com and www.puro.earth, accessed on 18 June 2021). There is, however, a lack of data and evidence on factors influencing the consumer demand for such climate-positive measures 
within the agricultural sector. In the literature, there exists a large number of studies on the WTP regarding greenhouse gas (GHG) emission reductions in general, but in order to develop crowdfunding campaigns that would enable consumers to offset their emissions locally through specific, climate-friendly, and farm-level measures, novel insights are needed at local, national and international levels. We thus seek to investigate the following question: What factors determine the public's willingness to pay for crowdfunded, additional greenhouse gas mitigation and storage at agricultural farms, both locally and nationally?

While such a question has, to the best of our knowledge, not been studied before, answering these research questions entails exploring two main uncertainties. The first concerns the individual consumers' perceptions of responsibility and interest in contributing to climate measures within the agricultural sector. If people consider Norwegian agriculture to already be too highly state-regulated and subsidized, then they might not see it as their individual responsibility, either as green consumers or citizens, to financially support additional initiatives in agriculture.

Second, if there exists a broad, untapped interest among the public, how important are the degree of concern for climate change and the characteristics of the local agricultural climate measures themselves for their WTP? How do green consumers perceive what they are potentially buying or giving money to? We investigate which models of crowdfunding are preferred by the general public, and what price margin, i.e., WTP, they perceive for a set of greenhouse-gas mitigation measures.

\section{Background and Identification of Climate Measures on Norwegian Farms}

\subsection{Green Consumers: Motives for and Barriers against Buying Green and Locally}

The emergence of environmentally conscious consumers has led to a growing literature on the economics of morally contingent motivation [7]. According to Sparkman and Walton [8], consumers will aim to "conform to normative information about other people's current attitudes" on which products are morally superior to buy. As Nyborg, Howarth and Brekke [9] point out, "such behavior is plainly at odds with the traditional assumption that consumers are rational actors who pursue a narrow conception of self-interest" [9] (p. 352). Consequently, Nyborg et al. [9] maintain that consumers might gain a benefit by choosing a morally superior, green product, equal to the value of attaining a more favorable self-image. The extent to which a consumer "acknowledges a personal responsibility for the issue at hand" determines its subjective benefit [9] (p. 352). In other words, if you believe that your actions lead to climate change and that this has negative consequences, your concern will motivate you to counteract this.

Identifying the total amount that individuals are willing to pay, in their role of green consumers, to reduce greenhouse gas emissions cannot be achieved from looking at current market indices. As the price of carbon is usually not specified in regular consumer exchanges, these prices need to be conferred indirectly, often through contingent valuation (CV) methodology. A contingent valuation captures the added value that consumers associate with a given service or product, such as a campaign for improving the state of the environment. Consumer attitude surveys, often employed to investigate individuals' interest in "green products", consistently identify a disposition to choose products displaying higher quality and safety standards, often associated with sustainability [10].

The individual WTP for environmental (public) goods also depends on one's perceptions of personal risks, environmental benefits and the costs of inaction (replacement costs or existence/bequest values). Stoknes [11,12] and others have argued that the individual perception of the urgency and pertinence of global warming depends on five key psychological barriers. The first relates to the perceived distance between the individual, on the one hand, and both the climate problem and its solutions on the other. In many ways, the Earth's climate problems, as well as solutions such as emission trading systems (like the EU's ETS) and global offsetting (like the UN's clean development mechanism, the CDM) remain something psychologically distant to most people. Cognitive dissonance is another key barrier. If what we know to be the "correct", sustainable behavior conflicts with our 
current unsustainable behavior, we often resign ourselves to and even disregard such facts altogether, in order not to have to deal with the incongruence. In such cases, denial of the problem might occur. Denying that climate change is happening altogether or taking comfort in the idea that it might be happening regardless of human actions allows people to avoid the uncomfortable dissonance between what they do and what they believe. The social and political identity of people is yet another barrier [12]. Indeed, systems of understanding, valuing, and filtering information are often centered on cultural and historical identities formed through kinship and cultural values, rather than on a factual basis.

Key to the concept of local crowdfunding of climate measures in the agricultural sector is whether people ascribe a higher value to local causes, those that are visible in their neighborhood. Taking action to influence the emissions and sites nearest ourselves lessens the psychological distance and dissonance [12] (p. 102). Given that most existing carbon offsetting schemes are targeting mostly distant climate mitigation projects at the international level, such as the UN CDM carbon offsets or EU ETS allowances, our study sought to test whether local measures would generate a higher level of interest among the population.

Feitelson [13] first used the term "place attachment" to refer to the "emotional bonds that arise from familiarity, a sense of belonging or ideology that plays a role in motivating individuals to attend to, care for and take actions on behalf of particular places" [14] (p. 61). This relates to a broader argument by Hulme [15] that climate change issues are situationally perceived, incorporating people's relationship with places. Attachments to an area perceived as "home" comprise a special form of "place", and the degree to which this attachment exists seems to be associated with factors such as "length of dwelling, property ownership, high perceived neighborhood cohesion", a high feeling of safety, and different forms of action and pro-environmental behaviors [14] (p. 62). According to Devine-Wright [14], there is a body of evidence describing "the role of place attachments in predicting attitudes toward low carbon energy projects". In one study, place attachments explained $20 \%$ of the variance in attitudes toward low-carbon energy projects in that neighborhood [14].

\subsection{Selected Studies of WTP of Climate Measures}

A range of international studies indicates that people are indeed willing to pay for mitigating carbon emissions. Investigating the WTP for carbon emissions reductions regarding car use, Hulshof and Mulder [16] found that, on average, a Dutch person was willing to pay EUR 199 per $\mathrm{tCO}_{2}$ emitted in driving (USD 210/tCO ), when considering what car to buy. MacKerron et al. [17] found that the mean WTP for a flight's verified carbon offset among young British adults was GBP 24 per person (USD $\sim 30 / \mathrm{tCO}_{2 \mathrm{e}}$ ). Citing Nyborg et al. [9], they identified that "a number of respondents who were unwilling to pay said they would be happy to do so if this were made a collective obligation, or if they believed that others would do so too" [17] (p. 1379). Kotchen, Boyle and Leiserowitz [18] studied attitudes toward paying a premium on carbon pollution in order to achieve the US 2020 climate target (17\% reduction). They found that, on average, each person was willing to pay between USD 79 and USD 89 per year. They also found that the WTP was highly sensitive to educational level, household income and age. They also attributed the variance to opinions about climate change [18].

Kragt, Gibson, Maseyk and Wilson [19] concluded that Australians were willing to pay approximately AUD 1.13 AUD per $\mathrm{tCO}_{2 \mathrm{e}}$ (approx. USD 1/tCO $\mathrm{CO}_{2 \mathrm{e}}$ ) reduction in Australian agriculture, through a nationwide carbon farming scheme. They also recorded a WTP for restoring and protecting native vegetation to be AUD 19 per hectare (approx. USD 14/ha) of increase in farmland area. Researchers from Statistics Norway (SSB) have investigated the Norwegian public's WTP for preserving agricultural landscapes in rural areas of Norway [20]. They find that, overall, the Norwegian population price the current cultural landscape and biodiversity values at a high level. Their study indicates that the rural populations living close to abandoned pastures have a higher WTP than urban 
and semi-urban residents, but that non-use values from ecosystem attributes such as carbon sequestration and biodiversity are constant across the country [20] (p. 1). In a similar fashion, a recent study of Finnish consumers identified a significant valuation of the "ecological and socio-cultural benefits of diversified food production systems in Finland" [21] (p. 988).

\subsection{The Identification of Relevant Measures for GHG Mitigation in Norwegian Farms}

When aiming to mitigate and reduce net emissions from farming, there are a number of GHG sources in the Norwegian agricultural sector that are relevant to consider. While this study examines WTP among consumers, a related study has examined the Norwegian farmers' willingness to participate in a local climate crowdfunding program [1]. Based on this large national survey of the supply-side, i.e., the farmers, four mitigation options were identified as the most relevant climate measures. Three criteria were applied when identifying which measures to include in the demand-side of the survey: (1) the measure must be practically feasible for the farmers to implement; (2) the measure needs to show clear mitigation benefits at local farms in Norwegian agriculture, and (3) the measure must provide several benefits at farm-level, ranging from improved resource utilization, cost savings or improved soil quality while reducing emissions. The four selected measures were: solar panels on the barn roof, biogas from animal manure, drag hoses for improved manure dispersal, and the addition of biochar to soils. Table 1 summarizes some of the most important context for the Norwegian agricultural sector as well as the national Crowdfunding market.

Table 1. Characteristics of the structure of the Norwegian agriculture and crowdfunding markets.

\begin{tabular}{|c|c|}
\hline Category & Unit \\
\hline Number of farms [22] & No. of businesses \\
\hline Large (>30 hectares) & 10,373 \\
\hline Medium (5-30 hectares) & 22,256 \\
\hline Small $(<5$ hectares $)$ & 21,305 \\
\hline Average production volume (for human consumption) [23] & in 1000 tons \\
\hline Meat & 348 \\
\hline Vegetables and fruit & 219 \\
\hline Cereals & 1607 \\
\hline Biochar production capacity in Norway $(2020$, tons per year) [24] & 1800 \\
\hline Crowdfunding in Norway, total turnover (2020, mNOK) [25] & 892 \\
\hline
\end{tabular}
Source: [22-25].

Several farmers have installed solar panels on their barn's roof. The barn roof surfaces are large and often shade-free. Solar panels could increase the share of renewable energy consumption if the energy gained replaces that of fossil fuels. The energy received by the solar panels must be utilized immediately; therefore, the farm energy demand has to be closely coupled to the solar panel production profile and storage, in order for it to be a cost-effective solution. In Table 2, we used the European mix (396 $\left.\mathrm{g} \mathrm{CO}_{2} / \mathrm{kWh}\right)$, as this paper has international relevance. Estimates with the Norwegian mix $\left(31 \mathrm{~g} \mathrm{CO}_{2} / \mathrm{kWh}\right)$ are given in Supplement 1 (Supplementary Materials). The latter mix results in the estimated impact of electricity use on GHG emissions being much lower, due to the high share of hydropower in the Norwegian electricity mix (95-98\%) (see Supplement 1 for details and assumptions for all four measures). 
Table 2. Estimated annual on-farm emissions reductions for four agricultural measures.

\begin{tabular}{|c|c|c|c|}
\hline Climate Measure & Main Mechanism and Impact & $\begin{array}{c}\text { Tons } \mathrm{CO}_{2 \mathrm{e}} \\
\text { Saved/Year }\end{array}$ & $\begin{array}{c}\text { Cost per } \mathrm{kgCO}_{2 \mathrm{e}} \text { in } \\
\mathrm{NOK}\end{array}$ \\
\hline Solar power on barn roof & Production and source of electric energy & 22 & 46 \\
\hline $\begin{array}{l}\text { Biogas plant, based on the } \\
\text { farm's own manure }\end{array}$ & $\begin{array}{l}\text { Production of electric energy/reduced } \mathrm{CH}_{4} \\
\text { emission from manure storage/improved } \\
\text { fertilization effect of manure, and thus, a reduced } \\
\text { need for fertilizer purchase }\end{array}$ & 150 & 40 \\
\hline $\begin{array}{l}\text { Drag hose with dribble bars } \\
\text { for manure spraying }\end{array}$ & $\begin{array}{l}\text { Reduced } \mathrm{NH}_{3} \text { volatilization during the spraying of } \\
\text { manure and } \mathrm{N}_{2} \mathrm{O} \text { emission after spraying, } \\
\text { improved fertilization effect of manure, and thus, a } \\
\text { reduced need for fertilizer purchase. Less energy } \\
\text { used for manure spraying }\end{array}$ & 11,600 & 1.2 \\
\hline $\begin{array}{l}\text { Pyrolysis of the farm's wood } \\
\text { chip to biochar }\end{array}$ & Increased carbon soil storage, syngas and heat & 116 & 16 \\
\hline
\end{tabular}

Note: The impacts from a reduced need for electricity, lower greenhouse gas emissions or increased carbon storage are estimated as emitted $\mathrm{CO}_{2 \mathrm{e}}$ at present, minus the emitted $\mathrm{CO}_{2 \mathrm{e}}$ with the measure. European grid mix is used for $\mathrm{CO}_{2 \mathrm{e}}$ related to used or saved electrical energy. See Supplementary Materials for details. Emission reduction potentials are estimated based on field research on the Skaun dairy farm in Trøndelag, Norway.

The production of biogas from animal manure leads to reduced emissions of methane and nitrous oxide from fertilizer storage, and reduced emissions of $\mathrm{CO}_{2}$ if the biogas replaces fossil-fuel diesel or heating oil [26], but the investment cost is relatively high for small farms [27]. Farm-scale biogas production has a high climate potential but is still in its infancy in Norway. Costs and mitigation benefits depend on several factors, such as the reduced storage time of livestock manure, the degree of utilization, transport distance, and the use of biogas and bio residues/digestate. For smaller farms, especially dairy farms, where quantities of manure are produced, the investment cost of a biogas plant can be high ( $>5$ million NOK). Coupled with a typical modest energy demand relative to energy production, it is not straightforward to realize economically viable plants. Now, plants are being realized at relatively large farms that have a correspondingly high energy demand. Farm-scale plants can receive funding from Innovation Norway ( $50 \%$ of the investment cost).

Using a drag hose, in combination with dribble bars, is an efficient way to improve manure management at the farm level. With a drag hose, the manure is transported through a hose connected to a tractor instead of being transported with a slurry tanker. This saves energy for the transport of heavy slurry. In addition, the energy used for the pump can be from electrical energy based on renewable sources. With dribble bars, manure is pumped from the drag hose to a series of separate hanging hoses. The combination of a drag hose and dribble bars does increase the nitrogen efficiency of added slurry. This leads to a reduced need for purchased fertilizer nitrogen and, thus, to less energy used for the production and transport of fertilizer nitrogen and lower emissions of the GHG nitrous oxide $\left(\mathrm{N}_{2} \mathrm{O}\right)$ from the production and use of fertilizer nitrogen. Reduced ammonia volatilization and reduced soil compaction are important for enhanced nitrogen efficiency. Reduced soil compaction will also decrease nitrous oxide emissions from applied nitrogen through manure and fertilizers [28,29]. $\mathrm{N}_{2} \mathrm{O}$ is the largest source of GHG, from manuring and fertilizing the soil. Thus, reduced $\mathrm{N}_{2} \mathrm{O}$ emissions through an improved manure strategy will have a large impact on GHG emissions.

Biochar is a solid material obtained from the thermochemical carbonization of biomass (such as wood, manure, or leaves) in an oxygen-limited environment. The reason for the large focus on biochar over the last few years is the stabilization of carbon that occurs during pyrolysis. The aim is to utilize this to increase carbon storage in soils and, at the same time, improve the soil's agronomic performance and reduce $\mathrm{N}_{2} \mathrm{O}$ emissions from the soil [30]. In addition to stable carbon biochar, the process also produces syngas and 
heat, which can be utilized for energy consumption. The climate potential is assumed to be high [31], but so far there only exist a few pilot units in Norway. In order to reduce emissions from agriculture by $10 \%$ by 2030 , there is a need for $500-9000$ extra pyrolysis units [26]. To utilize biochar efficiently, more knowledge is needed on which organic materials are most suitable to use for biochar production under Norwegian conditions, along with the most suitable temperatures and pyrolysis technologies, and how much carbon would be stored in the soil from the long-term perspective. The estimates given in the present article are based on a few Norwegian pioneer plants, with high uncertainty, as the underlying data are sparse.

At present, none of these climate measures seem viable for the individual farmer to be able to afford to invest in. All else being equal, we infer that the existing support scheme for Norwegian farmers will not result in new substantial investments that will realize these measures. In the absence of new initiatives, we hence investigate the potentiality of a novel approach to raising funds, i.e., crowdfunding campaigns, and their role in achieving further emissions reductions in Norwegian agriculture.

\subsection{Hypotheses}

One key attribute of the measures is the immediate comprehensibility and visibility of the measures when installed and operational at the farm. Based on the literature above and the data from the focus groups we conducted, there is reason to expect a positive relationship between climate measures that are deemed salient, comprehensible and visible at the local level, and a willingness to crowdfund these types of climate technologies. This could create a certain bias toward tangible measures that people are used to seeing in their local areas and want to see more of (like solar panels), irrespective of their real abatement potential. We constructed a conceptual model, Figure 1, showing the attributes of the different climate technologies

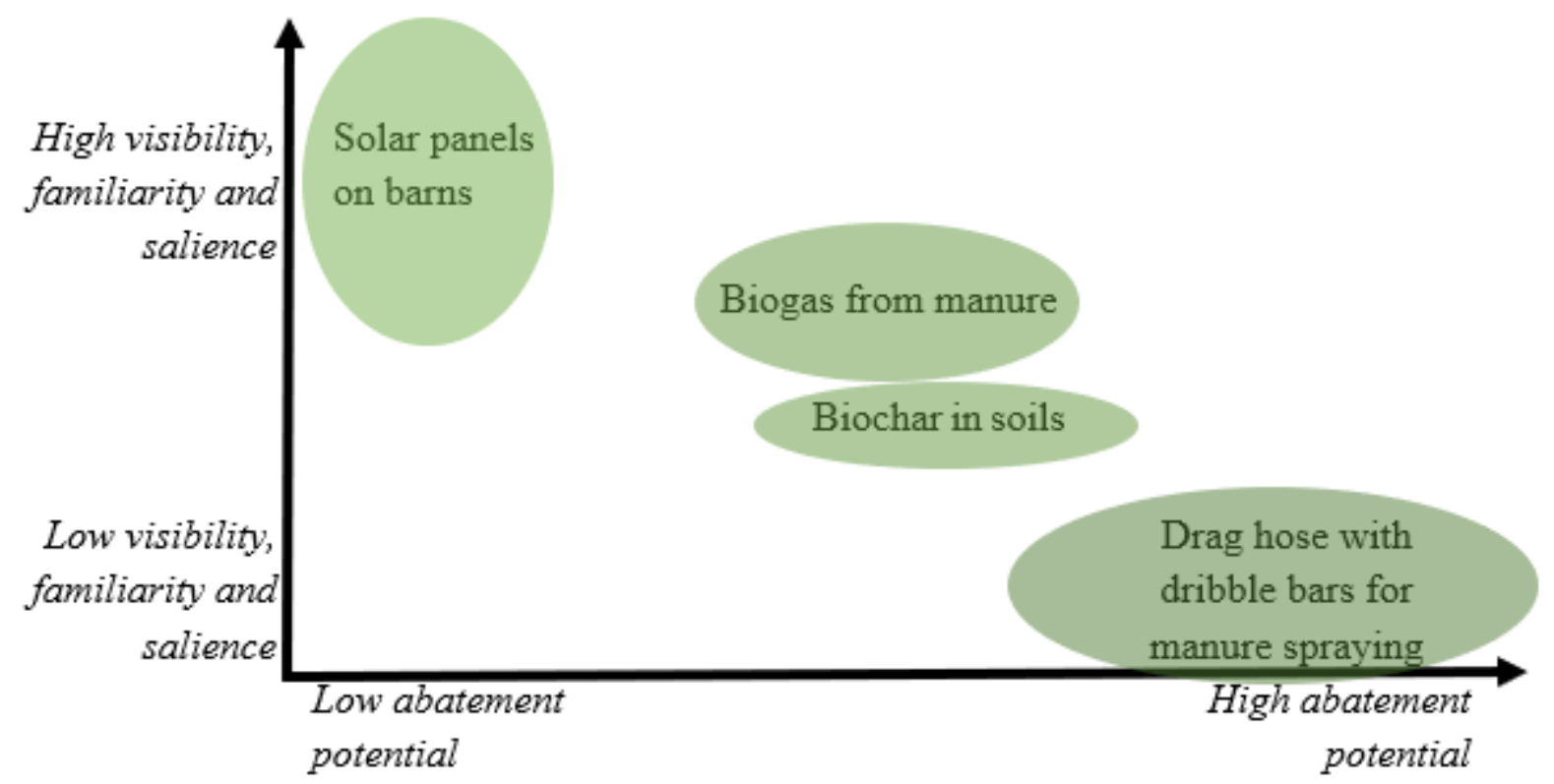

Figure 1. Conceptual model of the relationship between climate abatement potential and the visibility and salience of relevant climate measures in agriculture.

Building on the above, we sought to test the following hypotheses:

Hypothesis H1. There is a commercially significant interest among the Norwegian public for crowdfunding climate measures in agriculture. 
If $\mathrm{H} 1$ is not falsified, then at least three secondary hypotheses, one for each major consumer factor, i.e., climate concern, proximity, and comprehensibility, are crucial for the future design of successful CF initiatives:

Hypothesis H2a. The willingness-to-pay (WTP) is higher with attitudes of higher climate concern.

Hypothesis $\mathbf{H 2 b}$. The WTP is higher, the more local a farm measure is perceived to be.

Hypothesis H2c. The WTP is higher for measures perceived as well-known, comprehensible and salient.

\section{Materials and Methods}

Contingent valuation [32] is a common valuation method applied when there is no established market for the exchange of goods in question, or where the benefits of the goods are public in nature [33]. We investigate the public's willingness to pay to compensate for their own emission footprint by participating in crowdfunding campaigns for climate mitigation through local agriculture activities. The perceived utility here is an environmental, non-monetary attribute of reduced GHG emissions at the farmlevel, close to where the contributor lives. In line with Nyborg et al. [9], we assume that economic agents also seek to make socially responsible investments, thus providing the necessary incentive for individuals to pay a certain premium for achieving environmentally desirable objectives.

Building on results from related research on the farmers' willingness to invest in extra climate measures [1], we designed a double-bounded contingent valuation experiment to capture the stated preferences of the Norwegian population for crowdfunding one or several of the four climate measures identified as being most suitable for application on Norwegian farms. Respondents were asked to indicate how much they would be willing to contribute to each of these measures, given the premise that they were offered through local crowdfunding campaigns at an imagined farm in their neighborhood. We decided on using an online form rather than performing field surveys, as they have several advantages: (1) they are an affordable way of reaching a larger proportion of the overall population in a geographically dispersed country such as Norway, (2) they do not suffer from interviewer bias, and (3) respondents are likely to feel more comfortable when answering sensitive questions and moving through the survey at their own pace. Still, online surveys also come with disadvantages: unlike face-to-face or telephone surveys, it is impossible to offer any clarification of questions, and some respondents may not fully comprehend what is being asked of them [17].

Contingent valuation methods do have a range of limitations and biases, common to all types of stated-preference valuations. Previous research highlights that stated preferences do not always match the revealed preferences or the actual WTP. This can be due to the wellknown "hypothetical bias" and the risk of "cheap talk", where people tend to oversell their true WTP [34]. There is a risk of "complacency bias", where survey participants respond according to how they suspect the researchers want them to reply (sometimes referred to as social desirability bias, with respondents wanting to adhere to the social norms for the topic in question). In our case, there is a particular risk of "ill-formed preferences", in cases where respondents have not fully understood the alternative goods offered to them in the choice experiment. A final concern with this type of choice experiment survey is the risk of respondents answering strategically, in a way that is different from their true preferences. This is sometimes referred to as "strategic bias", where the key factor is whether the respondent has a special, pre-existing self-interest in the survey's reaching a certain conclusion [32,33].

\subsection{Mixed Methods Approach to Contingent Valuation Based on a National Survey}

Our aim was to investigate the factors that influence the Norwegian public's willingness to pay (WTP) regarding local crowdfunding campaigns aimed at reducing GHG 
emissions from Norwegian farms. We designed a national-level survey with a contingent valuation $(\mathrm{CV})$ experiment on four key crowdfunding targets. The CV survey was modeled on similar attempts at CV in the literature $[16,19,21]$, and was based on inputs from an interdisciplinary consortium of researchers, three focus groups, and a pre-test with 35 respondents.

To qualitatively explore the attitudes, understanding, concerns, and preferences for the measures among laypeople, we conducted three focus groups at the beginning of the data collection period. Focus-group methodology is widely used and allows a project to follow a well-established methodology and validity [35]. It also allowed research informants to explain not only what, or how much, but also why they think the way that they do. Two of the focus groups consisted of participants who were recruited individually, and one focus group consisted of people from the same company, a regional power utility. It gave us a total of 19 participants across the three focus groups. All participants were living in and around Oslo, eastern Norway.

The focus groups were sampled, based on the strategic selection of key stakeholder groups considered to be of interest to the concept design. Our focus group participants represented a good mix of gender, age, education, and work status. With little or no connections to agriculture, they originated from various parts of Norway, although they were currently living in and around Oslo. They were all recruited through the network of the project members.

The online survey was designed in four main parts: the first had an introductory section and inquired into the demographics of the respondents. The second part delved into respondent's attitudes to supporting climate change measures and to Norwegian agriculture. The third part started with a general introduction to crowdfunding and the different funding models, before introducing the choice experiment, and asked respondents to estimate their WTP for the four climate solutions. The fourth and final part explored perceptions about responsibility and agency for climate measures in Norwegian agriculture.

In the choice experiment, each measure was described as it would appear on a crowdfunding campaign website, with a short piece of text and a photo illustrating how this technology could look at the local-farm level. The texts were written as neutrally as possible, aiming to present each case as being equally attractive. Among the benefits mentioned was how each measure could help the farmer reduce emissions, improve soil quality, and cut future costs, but without giving specific mitigation numbers, as these are highly uncertain. We asked respondents to indicate how much they would be willing to contribute for each measure at the farm level, considered separately, by typing a discrete number between NOK 0 and 1000 (Norwegian kroner) (approximately USD 100 at 2021 currency rates).

\subsection{Sampling and Recruitment Strategy}

The survey responses were collected using a professional survey panel, representing the overall Norwegian population, as of 2019. The survey was randomly administered by Userneeds, a survey service company, until 1500 survey responses were collected. The survey was administered in February 2020. We were especially interested in sampling across all regions of the country, both in rural and urban areas, proportional to the national population.

Our relatively large survey sample (1500 respondents) matches the Norwegian adult population quite closely, with median income levels a little above the national median and a larger proportion claiming a work-related relationship to agriculture.

\section{Results}

The majority of the informants still believe that climate change is not mainly anthropogenic (see Table 3: $34 \%+14 \%+4 \%=52 \%$ ), contradicting the climate science consensus [36,37]. Only 39\% state that it is mainly anthropogenic. Almost 2 in $3(61 \%)$ claim to have good or adequate knowledge about climate change in agriculture. 
Table 3. Respondent attitudes to climate change causation, agricultural knowledge, proximity and crowdfunding $(\mathrm{N}=1500)$.

\begin{tabular}{ccc}
\hline Which of the Following Matches Your View? & No. of Respondents & Share \% \\
\hline Climate change is exclusively natural & 63 & $4 \%$ \\
Climate change is mainly natural & 211 & $14 \%$ \\
Climate change is equally natural and anthropogenic & 514 & $34 \%$ \\
Climate change is mainly anthropogenic & 587 & $39 \%$ \\
Climate change is exclusively anthropogenic & 61 & $4 \%$ \\
I don't believe that climate change is happening & 20 & $1 \%$ \\
Don't know & 44 & $2 \%$ \\
\hline
\end{tabular}

We also find that $48 \%$ are familiar with the concept of crowdfunding (Table 4 ). One in three agrees that the crowdfunding of climate measures can be a good solution for agriculture. On knowledge and preferences regarding the four possible crowdfunding models (donations, rewards, lending, equity), the most popular is donations, i.e., a gift to the farm. In fact, $34 \%$ of our sample state that-if they are going to support the schemethey are likely to choose this model. Only $15 \%$ would consider lending, and $21 \%$ would consider equity (multiple choices possible). The type of actor perceived as most trustworthy to operate crowdfunding campaigns for the agricultural sector is research institutes.

Table 4. Respondent attitudes to climate change in agriculture and crowdfunding ( $\mathrm{N}=1500)$.

\begin{tabular}{ccccc}
\hline How Do You View Your Own & Good & Adequate & Poor & Don't Know \\
\hline $\begin{array}{c}\text { knowledge about climate change in } \\
\text { agriculture: }\end{array}$ & $23 \%$ & $38 \%$ & $34 \%$ & $6 \%$ \\
\hline How likely are you to donate to & Likely & Somewhat & Unlikely & Don't know \\
\hline local climate measures & $33 \%$ & $29 \%$ & $31 \%$ & $8 \%$ \\
\hline national climate measures & $26 \%$ & $32 \%$ & $35 \%$ & $8 \%$ \\
\hline international climate measures & $25 \%$ & $29 \%$ & $39 \%$ & $7 \%$ \\
\hline Have you previously encountered & Yes & No & & \\
\cline { 1 - 3 } the term “crowdfunding” & $48 \%$ & $52 \%$ & & Don't know \\
\hline To crowdfund climate solutions & Agree & Somewhat & Disagree & 19\% \\
\hline is a good solution for agriculture & $33 \%$ & $25 \%$ & $23 \%$ & \\
\hline
\end{tabular}

Our main research question is whether there is a significant level of WTP to make successful crowdfunding of farm-level climate measures feasible in Norway (H1). Onethird $(31 \%)$ say that they are not likely to donate to local climate solutions, while onethird (29\%) say they are somewhat likely to do so, and the final third (33\%) say they are likely. With two-thirds of the population expressing some interest in crowdfunding, these responses give some support to hypothesis H1. The share of respondents that are likely to support local measures is $8 \%$ higher than those that are willing to support international measures, hence giving weak support to $\mathrm{H} 2 \mathrm{~b}$.

Table 5 summarize the mean willingness to pay (WTP) across measures, for all sociodemographic categories in the survey, as well as per measure. Across the entire sample, the individual average WTP per measure, i.e., one potential crowdfunded investment on one farm, is NOK 161 (USD 18 in 2020). The standard deviations are large, indicating a very large variability in WTP. With "average WTP" we refer to their mean willingness-to-pay across the four measures (average WTP $=(\mathrm{M} 1+\mathrm{M} 2+\mathrm{M} 3+\mathrm{M} 4) / 4$ for each person). Among the socio-demographic factors (described in Table 6), we find a higher WTP among people who are younger, have higher incomes, have agriculture-related employment, and believe climate change is mainly or fully anthropogenic. The latter lends some support to $\mathrm{H} 2 \mathrm{a}$; the correlation coefficient $(r=0.09)$ is statistically significant but not strong (see Table 6). Other 
factors have a stronger correlation with WTP, such as age $(\mathrm{r}=-0.30)$ and their attitude to $\mathrm{CF}$ as a good climate solution $(\mathrm{r}=0.42)$. The covariation matrix (Table 7$)$ further illustrates that most attitudes varies with the attributes age, education and income.

Table 5. Average WTP, by socio-demographic characteristics, attitudes, and measure.

\begin{tabular}{|c|c|c|c|c|}
\hline Category & Mean WTP & Std. Dev & \multicolumn{2}{|c|}{ Std. Error } \\
\hline All & $161 \mathrm{kr}$ & 239 & \multicolumn{2}{|c|}{6} \\
\hline Male & $172 \mathrm{kr}$ & 253 & \multicolumn{2}{|c|}{8} \\
\hline Female & $148 \mathrm{kr}$ & 220 & \multicolumn{2}{|c|}{9} \\
\hline Age: $18-34$ & $247 \mathrm{kr}$ & 264 & \multicolumn{2}{|c|}{12} \\
\hline Age: $35-49$ & $126 \mathrm{kr}$ & 204 & \multicolumn{2}{|c|}{12} \\
\hline Age: >50 & $132 \mathrm{kr}$ & 229 & \multicolumn{2}{|c|}{8} \\
\hline Low Education (no sec. school) & $140 \mathrm{kr}$ & 230 & \multicolumn{2}{|c|}{25} \\
\hline Mid Educ. (practical sec. school) & $151 \mathrm{kr}$ & 252 & \multicolumn{2}{|c|}{14} \\
\hline Mid Educ. (academic sec. school) & $172 \mathrm{kr}$ & 248 & \multicolumn{2}{|c|}{15} \\
\hline High Educ. (<4 yrs univ.) & $155 \mathrm{kr}$ & 227 & \multicolumn{2}{|c|}{10} \\
\hline Very High (>4 yrs univ.) & $180 \mathrm{kr}$ & 243 & \multicolumn{2}{|c|}{13} \\
\hline Low income $(<400,000$ kroner $)$ & $151 \mathrm{kr}$ & 231 & \multicolumn{2}{|c|}{11} \\
\hline Middle income $(400,000-800,000$ kroner $)$ & $192 \mathrm{kr}$ & 259 & \multicolumn{2}{|c|}{20} \\
\hline High income $(800,000-1,000,000+$ kroner $)$ & $196 \mathrm{kr}$ & 267 & \multicolumn{2}{|c|}{35} \\
\hline Employed in primary sector (1) & $335 \mathrm{kr}$ & 293 & \multicolumn{2}{|c|}{22} \\
\hline Not in primary sector (2) & $137 \mathrm{kr}$ & 220 & \multicolumn{2}{|c|}{6} \\
\hline Did not answer (3) & $230 \mathrm{kr}$ & 274 & \multicolumn{2}{|c|}{52} \\
\hline Climate change (CC) natural (1) & $151 \mathrm{kr}$ & 275 & \multicolumn{2}{|c|}{30} \\
\hline CC mostly natural (2) & $142 \mathrm{kr}$ & 243 & \multicolumn{2}{|c|}{16} \\
\hline CC both natural and anthropogenic (3) & $150 \mathrm{kr}$ & 240 & \multicolumn{2}{|c|}{10} \\
\hline CC mostly anthropogenic (4) & $182 \mathrm{kr}$ & 232 & \multicolumn{2}{|c|}{10} \\
\hline CC fully anthropogenic (5) & $233 \mathrm{kr}$ & 273 & \multicolumn{2}{|c|}{31} \\
\hline CC not happening (6) & $81 \mathrm{kr}$ & 158 & \multicolumn{2}{|c|}{53} \\
\hline Likely to give locally (1) & $342 \mathrm{kr}$ & 314 & \multicolumn{2}{|c|}{16} \\
\hline Neither likely nor unlikely (2) & $151 \mathrm{kr}$ & 228 & \multicolumn{2}{|c|}{11} \\
\hline Not likely to give locally (3) & $55 \mathrm{kr}$ & 138 & \multicolumn{2}{|c|}{15} \\
\hline WTP per measure, sorted by mean WTP & Mean WTP & Std. error & CI 95\% UB & CI 95\% LB \\
\hline Solar panels & $187 \mathrm{kr}$ & 7.6 & 202 & 172 \\
\hline Biogas plant & $177 \mathrm{kr}$ & 7.3 & 191 & 163 \\
\hline Drag hose & $142 \mathrm{kr}$ & 6.5 & 155 & 129 \\
\hline Biochar unit & $141 \mathrm{kr}$ & 6.5 & 153 & 128 \\
\hline
\end{tabular}

Table 6. Correlation between WTP and socio-demographic variables and attitudes.

\begin{tabular}{ccc}
\hline Variables vs. WTP & CORR & $p$-Value \\
\hline Age $\times$ WTP & $-0.30^{* * *}$ & 0.0001 \\
Gender $\times$ WTP & $-0.05^{*}$ & 0.0488 \\
Income $\times$ WTP & 0.09 & 0.1584 \\
Employment in agric. $\times$ WTP & $0.27^{* * *}$ & 0.0001 \\
Education level $\times$ WTP & 0.05 & 0.4007 \\
Climate attitude $\times$ WTP & $0.09^{*}$ & 0.0205 \\
Climate change impact on agriculture & $0.14^{* * *}$ & 0.0001 \\
CF is a good climate solution & $0.42^{* * *}$ & 0.0001 \\
Only support local farmer & $0.17^{* * *}$ & 0.0001 \\
\hline
\end{tabular}


Table 7. Covariation matrix, respondent attributes and attitudes.

\begin{tabular}{ccccccc}
\hline Variable & Age & Education & Income & $\begin{array}{c}\text { Climate } \\
\text { Concern }\end{array}$ & $\begin{array}{c}\text { Impact of CC } \\
\text { on Agriculture }\end{array}$ & $\begin{array}{c}\text { CF a Good } \\
\text { Climate Solution }\end{array}$ \\
\hline $\begin{array}{c}\text { Climate concern } \\
\text { Impact of CC on }\end{array}$ & -0.07 & 0.09 & -0.04 & $X$ & $X$ & $X$ \\
$\begin{array}{c}\text { agriculture } \\
\text { CF is a good climate }\end{array}$ & 0.02 & -0.12 & -0.02 & -0.25 & & $X$ \\
$\begin{array}{c}\text { solution } \\
\text { Only local farmer }\end{array}$ & 0.27 & -0.01 & 0.04 & -0.19 & 0.17 & $X$ \\
\hline
\end{tabular}

(Correlation estimates based on CORREL-function in Excel; $\mathrm{CF}=$ crowdfunding, $\mathrm{CC}=$ climate change).

\section{Discussion}

Is there a commercially significant interest among the public to crowdfund climate measures in local agriculture (H1)? Several findings support hypothesis H1: 61\% claim to have (at least adequate) knowledge of climate change in agriculture, $77 \%$ acknowledge some anthropogenic causation of worsening climate change, and one-third (33\%) say they are likely to donate.

The survey respondents' stated WTP, however, is, on average, on the low side of the spectrum, from NOK 0-1000: NOK 161 (USD 18) per measure. The WTP of the 33\% segment who stated they are likely to donate, jumps to exactly double: NOK 323 (USD 36) per campaign. To illustrate what this requires: if a typical farm wants to invest in a climate measure where NOK $\sim 300,000$ of extra funding is needed in order to trigger farmer investment decision with (some) state support, the crowdfunding campaign would then need to successfully reach around 1000 people with the attitude of "likely to donate" to this farm, or 2000 people with average contributions, for the campaign to reach its target in time. This outcome also assumes that the stated WTP would translate into actual payments. There is therefore good reason to doubt the realism of public crowdfunding providing a commercially significant investment for realizing climate measures in agriculture, all else being equal.

Social media do substantially reduce the transaction costs of outreach and a large number of transfers to the farmer and the crowdfunding platform. Still, for an average farm campaign to secure funding from up to 2000 givers is clearly a major challenge. An even more expensive measure, such as an on-site farm biogas plant, can be 10 times more expensive, with an additional NOK $3 \mathrm{~m}$ of funds needed to trigger investment. For one farm (or even one group of farms) to crowdfund one biogas plant, then, would require between 10,000-20,000 donors, something which-in our view-pushes the concept into the realm of the clearly infeasible for more expensive measures, an argument that weakens the overall support for hypothesis $\mathrm{H} 1$.

\subsection{The Green Consumer - Is Personal Responsibility for Climate a Motivating Factor? (H2a)}

Does the public perceive the consumer, the farmer, or the state to be most responsible for mitigating agricultural emissions? The question of individual vs. structural or collective responsibility for climate mitigation has been a critical issue in the climate debate for decades [12,15]. This new possibility of digital crowdfunding can in many ways bring all these threads and actors together: In the absence of ambitious top-down regulations and structural frameworks for effective mitigation, the new crowdfunding platforms can in theory engage individuals in supporting farmers through the needed private capital to match public funds, so as to realize investments in climate solutions that are otherwise too costly.

Our survey queried the informants' attitude to climate change causation, in order to tap into the public perception of human responsibility for climate change. We know from previous studies that more than $96 \%$ of the Norwegian population acknowledges the reality of climate change $[37,38]$. Other studies show a strong correlation between belief in anthropogenic climate change and a high degree of climate concern, sometimes referred to 
as "climate attitude" [36]. There is, however, substantially more ambivalence within the Norwegian population on the issue of whether humans are the dominant cause of global warming or not, and as such, to what degree the individual assumes responsibility for mitigation efforts $[37,38]$.

Our results do indicate a weak positive correlation between stronger attitudes to anthropogenic climate change and a higher WTP. However, there is also a very large standard deviation (typically NOK 240) relative to the average WTP (NOK 161). Hence, the correlation between WTP and "climate attitude" becomes low, at $\mathrm{r}=0.09$, with $p<0.02$. This indicates that there are several other factors at work explaining green consumers' WTP for climate measures in the agricultural sector, and that one's climate attitude does not have a strong effect on WTP. For instance, a significant segment $(19 \%$, an equal proportion of men and women, young and old) agree that animal welfare and environmental concerns are more important than climate change in Norwegian agriculture.

Overall, these results provide some, albeit weak, support for hypothesis H2a.

\subsection{Does Spatial Proximity to the Campaign Increase WTP? (H2b)}

Our study explored to what extent respondents are more interested in participating in crowdfunding campaigns that relate to their local neighborhood. Indeed, those who state that it is likely they would contribute to a climate measure at the local level have a much higher average WTP (NOK 342, Table 4) than those who express indifference (NOK 146) as to whether measures happen locally or internationally.

From the focus groups transcripts, we learned that the farm's being close by and local seemed to be important, but the definition of "local" is wide. Several mentioned that they would consider donating to a farmer located where they were themselves born, or somewhere where their family lives, so this is not only if the farmer is close to where they currently live. As one participant put it: "The closer and more visible it is, the simpler I think it is for you to join the common, shared contribution that this is." However, donating to a farmer from another country, "for instance, Sweden", was out of the question (focus-group participants).

From the survey results, there is no (strong) correlation between average WTP and attitudes to reducing emissions from agriculture in particular. Measures targeting other sectors hold as much attractivity, and agreeing with the statement, "I will only contribute if the funds go to a local farmer", only has a weak correlation to the average WTP $(r=0.17$, $p<0.001$.

On this topic, we find significant differences related to age. We see that the older population $(50+)$ places a greater emphasis on the tradition and cultural landscape in their image of agriculture in Norway than on climate. Thus, the oldest age bracket (50+) is willing to give more to a local campaign than is the middle-aged bracket (35-49). In addition, a larger share of older people (50+) than young people (18-34) will only give if the funds go to a local farmer ( $9 \%$ over $5 \%$ ).

Weighing the evidence above, particularly the fact that we do see the highest average WTP among those who indicate that they are likely to donate for local measures vs. international, it seems that $\mathrm{H} 2 \mathrm{~b}$ is moderately well supported.

\subsection{The Characteristics of Climate Measures in Agriculture-Comprehension and Salience (H2c)}

Most WTP studies explore the respondents' stated preferences for climate mitigation by finding ranges in the variable USD/ $\mathrm{tCO}_{2 \mathrm{e}}$; however, the uncertainty of agricultural emissions measures in (Nordic/Norwegian) agriculture makes it challenging to calculate the exact impact of investments in climate measures on the tons of GHG emissions from a specific farm per year.

From the focus groups, we learned that most of the participants know about solar panels and have heard about farmers investing in such technology, but almost none of the focus group participants knew about the other measures presented (biogas/drag hose/biochar). They expressed the opinion that they have little knowledge of whether 
these measures would actually help. Few participants were aware of their personal climate footprint in tons per year. The positive feedback on the solar panels also had to do with them being able to see the actual installation when passing by the farm or visiting. Most of them expressed interest in more information about the measures even if they had never heard about them before. As one participant expressed it: "I think that if it is an engaging measure, then one will give more. If one holds no opinion or have never heard of it, then one will disregard it" (from focus groups convened between November 2018 and September 2019).

The WTP results per measure reflect this order of comprehension and salience, in that solar panels were given the highest average at NOK 187, biogas, NOK 177, drag hoses, NOK 142, and biochar, NOK 141. Both drag hoses and biochar are more "invisible" results, as the impacts are mainly in the soil, and hence seem to evoke bewilderment and disengagement. As one participant put it: "I think it is smarter when you can actually see the results \{of the measure\}, so that you don't just pay a sum and it ends up in something very vague". The lack of information and experience, the novelty of the measures, with little previous government or media attention, seem to result in a low comprehension of and trust in the measure, which in turn impacts the WTP negatively.

Both the focus group and survey results indicate that comprehensibility, high visibility and salience have large impacts on WTP, strongly supporting H2c.

\subsection{Other Factors: The Importance of Familiarity with Crowdfunding and Storytelling}

Despite being introduced in the survey as "crowdfunding climate measures", other factors have a stronger correlation than climate concerns: age $(r=-0.30)$ and, in particular, their attitude to $C F$ as a good climate solution $(r=0.42)$. As researchers, we were surprised by the magnitude of the impact that familiarity with crowdfunding campaigns and platforms has on WTP.

The majority of participants in the focus groups mentioned the importance of getting to know the farmer "behind the campaign", seeing pictures and reading a story, but also seeing pictures of the farm, animals, and nature, framing the campaign with real-life images. None of the focus group participants, nor the survey participants, queried the exact mitigation efficiency of the measure, as measured in $\mathrm{USD} / \mathrm{tCO}_{2 \mathrm{e}}$.

\section{Conclusions}

In conclusion, we find supportive attitudes in the Norwegian population for crowdfunding climate measures, especially in local agriculture. However, the level of support as expressed in WTP may not be sufficient to trigger larger investments at the farm level. The WTP is somewhat higher among those that perceive climate change as mainly anthropogenic, and when the measures are at a local farm, relative to international measures, but these correlations are generally weak $(r=0.09$ and 0.17 , respectively). We found a higher WTP for measures that are easily comprehensible, visible and well-known, such as a solar panel (USD $\sim 20$ ) relative to those where the results are hard to grasp, invisible, or unknown, such as dribble-bars and biochar (USD 15), irrespective of that measure's climate mitigation potential. A surprising finding, to us, was that there is a much stronger correlation of WTP to attitudes and knowledge about crowdfunding as such, and particularly to crowdfunding as an enabler of climate solutions, than to factors such as climate concern, proximity, or mitigation potential.

The rational actor would only put his money on the measure with the best "bang for their buck", measured in $\mathrm{tCO}_{2 \mathrm{e}} / \mathrm{USD}$, but the real, human, consumer seems more motivated by norms and status concerns, and more persuaded by visible salience, stories about the farmer and the farm, animal welfare, and trust in the crowdfunding mechanism itself. In order to keep long-term trust and reliability, the campaigns would ideally be equipped with "carbon certificates", where the exact mitigation effect per measure and effect per USD is specified for each farm. The current state of knowledge does not permit this, due to the variety of conditions under which farms operate, and the lack of low-cost 
monitoring systems for emissions and carbon in soil levels per farm. More research could possibly meet these shortcomings by providing verifiable mitigation numbers in the future.

The implications for any crowdfunding campaigns of additional agricultural measures are that one should prioritize those measures that do not require too many small-level gift contributions to reach the investment threshold, with a high climate potential (such as dribble bars), and to dedicate considerable efforts to communicating the crowdfunding mechanisms, storytelling about the farmer, as well as visualizing how such measures work in order to maximize the WTP.

Supplementary Materials: The following are available online at https:/ / www.mdpi.com/article/10 $.3390 /$ su13169227/s1, Supplements 1-5 to Table 2 Estimated annual on-farm emissions reductions for four agricultural measures. Supplements 6 Survey form as distributed. Supplements 7: Survey raw data.

Author Contributions: Conceptualization, P.E.S. and O.B.S.; methodology, P.E.S.; software, O.B.S.; validation, S.H. and I.K.; formal analysis, S.W.S. and O.B.S.; investigation, P.E.S.; resources, P.E.S.; data curation, P.E.S., S.H. and I.K.; writing—original draft preparation, O.B.S.; writing-P.E.S., S.H., I.K. and S.W.S.; visualization, O.B.S.; supervision, P.E.S.; project administration, P.E.S., All authors have read and agreed to the published version of the manuscript.

Funding: This research was funded by The Research Council of Norway, KLIMAFORSK, 6362.00.

Institutional Review Board Statement: The study was conducted according to the guidelines of the Declaration of Helsinki, and approved by the Institutional Review Board (or Ethics Committee) of NSD-Norwegian centre for research data (protocol code 575842, approved: 18 January 2020).

Informed Consent Statement: Informed consent was obtained from all subjects involved in the study.

Data Availability Statement: The data set analyzed for the survey panel, in a simplified and anonymized format, as well as the farm-level emissions estimations are available from the corresponding author upon reasonable request.

Acknowledgments: The research was conducted under the auspices of the COOLCROWD project led by Pia Piroschka Otte with the support from the Research Council of Norway. We acknowledge valuable comments from Pia P. Otte, Marit Kragt, Rob Burton, Alexander Zahl-Thanem, Marit Sjøvaag and Tatiana Rittl. We thank all research participants, especially committed focus group panellists, for their feedback during the research process, including two anonymous reviewers.

Conflicts of Interest: The authors declare no conflict of interest.

\section{References}

1. Otte, P.P.; Zahl-Thanem, A.; Hansen, S.; Mæhle, N. Norwegian Farmers' Willingness to Participate in a Local Climate Crowdfunding Program-Results from a National Survey; Report 5/2019; RURALIS: Trondheim, Norway, 2019.

2. Kvakkestad, V.; Refsgaard, K.; Berglann, H. Citizen and Consumer Attitudes to Food and Food Production in Norway ; Discussion Paper, No. 2011-2; Norwegian Agricultural Economics Research Institute: Oslo, Norway, 2011.

3. Opinion. Hvordan Stiller Nordmenn Seg til Bærekraft og Grønn Omstilling? (Norwegian Attitudes to Sustainability and Green Transformation). 2020. Available online: https:/ / opinion.no/2020/05/hvordan-stiller-nordmenn-seg-til-baerekraft-og-gronnomstilling/ (accessed on 20 May 2020).

4. Aasen, M.; Klemetsen, M.E.; Reed, E.U.; Vatn, A. Folk og Klima: Nordmenns Holdninger til Klimaendringer, Klimapolitikk og Eget Ansvar (People and Climate: Norwegian Attitudes to Climate Change); CICERO: Oslo, Norway, 2019.

5. Kallbekken, S.; Aasen, M. The demand for earmarking: Results from a focus group study in Norway. Ecol. Econ. 2010, 69, 2183-2190. [CrossRef]

6. Kallbekken, S.; Sælen, H. Public acceptance for environmental taxes: Self-interest, environmental and distributional concerns. Energy Policy 2011, 39, 2966-2973. [CrossRef]

7. Wicker, P.; Becken, S. Conscientious vs ambivalent consumers: Do concerns about energy availability and climate change influence consumer behaviour? Ecol. Econ. 2013, 88, 41-48. [CrossRef]

8. Sparkman, G.; Walton, G.M. Dynamic Norms Promote Sustainable Behavior, Even if It Is Counternormative. Psychol. Sci. 2017, 28, 1663-1674. [CrossRef] [PubMed]

9. Nyborg, K.; Howarth, R.B.; Brekke, K.A. Green consumers and public policy: On socially contingent moral motivation. Resour. Energy Econ. 2006, 28, 351-366. [CrossRef] 
10. Nielsen. Sustainable Shoppers Buy the Change They Wish to See in the World; Nielsen: Oslo, Norway, 2018.

11. Stoknes, P.E. Rethinking climate communications and the "psychological climate paradox". Energy Res. Soc. Sci. 2014, 1, 161-170. [CrossRef]

12. Stoknes, P.E. What We Think about When We Try Not to Think About Global Warming; Chelsea Green: Hartford, VT, USA, 2015.

13. Feitelson, E. Sharing the globe: The role of attachment to place. Glob. Environ. Chang. 1991, 1, 396-406. [CrossRef]

14. Devine-Wright, P. Think global, act local? The relevance of place attachments and place identities in a climate changed world Glob. Environ. Chang. 2013, 23, 61-69. [CrossRef]

15. Hulme, M. The conquering of climate: Discourses of fear and their dissolution. Geogr. J. 2008, 174, 5-16. [CrossRef]

16. Hulshof, D.; Mulder, M. Willingness to Pay for $\mathrm{CO}_{2}$ Emission Reductions in Passenger Car Transport. Environ. Resour. Econ. 2020, 75, 899-929. [CrossRef]

17. MacKerron, G.J.; Egerton, C.; Gaskell, C.; Parpia, A.; Mourato, S. Willingness to pay for carbon offset certification and co-benefits among (high-)flying young adults in the UK. Energy Policy 2009, 37, 1372-1381. [CrossRef]

18. Kotchen, M.J.; Boyle, K.J.; Leiserowitz, A.A. Willingness-to-pay and policy-instrument choice for climate-change policy in the United States. Energy Policy 2013, 55, 617-625. [CrossRef]

19. Kragt, M.; Gibson, F.; Maseyk, F.; Wilson, K. Public willingness to pay for carbon farming and its co-benefits. Ecol. Econ. 2016, 126, 125-131. [CrossRef]

20. Kildal Iversen, E.; Grimsrud, K.M.; Lindhjem, H.; Bredahl Jacobsen, J. Trade-Offs between Carbon Sequestration, Land-Scape Aesthetics and Biodiversity in a Cost-Benefit Analysis of Land Use Options in Norway; Discussion Papers, No.915; Statistics Norway, Research Department: Oslo, Norway, 2019.

21. Latvala, T.; Regina, K.; Lehtonen, H. Evaluating Non-Market Values of Agroecological and Socio-Cultural Benefits of Diversified Cropping Systems. Environ. Manag. 2021, 67, 988-999. [CrossRef] [PubMed]

22. SSB. Gardsbruk, Jordbruksareal og Husdyr (Farms, Agricultural Areas and Livestock). 2021. Available online: https://www.ssb. no/jord-skog-jakt-og-fiskeri/jordbruk/statistikk/gardsbruk-jordbruksareal-og-husdyr (accessed on 4 June 2021).

23. SSB. Produksjon av Jordbruksprodukter (Production of Farm Products). 2020. Available online: https://www.ssb.no/jord-skogjakt-og-fiskeri/faktaside/jordbruk (accessed on 4 June 2021).

24. Norwegian Biochar Network. Produksjon av Biokull (Production of Biochar). 2020. Available online: https://www.biokull.info/ nyheter (accessed on 4 June 2021).

25. Skjelsbæk. Dobling for Norsk Folkefinansiering (Doubling of Norwegian Crowdfunding). 2021. Available online: https: / / shifter.no/nyheter/dobling-for-norsk-folkefinansiering/201302 (accessed on 4 June 2021).

26. Bardalen, A.; Rivedal, S.; Aune, A.; O’Toole, A.; Walland, F.; Silvennoinen, H.; Sturite, I.; Bøe, F.; Rasse, D.; Pettersen, I.; et al. Utslippsreduksjoner i Uorsk Jordbruk. Kunnskapsstatus og Tiltaksmuligheter. NIBIO Rapport Vol 4 (149). 84 s. 2018. Available online: https: / / nibio.brage.unit.no/nibio-xmlui/handle/11250/2577266 (accessed on 4 June 2021).

27. Lyng, K.; Callewaert, P.; Prestrud, K. Kunnskapsgrunnlag for Nasjonal Strategi for Husdyrgjødsel til Biogass-Produksjon Del 2 (Knowledge Basis for National Strategy on Biogas from Manure); Report. Nr OR.50.19; NORSUS: Fredrikstad, Norway, 2019.

28. Hansen, S.; Mæhlum, J.; Bakken, L. N2O and $\mathrm{CH}_{4}$ fluxes in soil influenced by fertilization and tractor traffic. Soil Biol. Biochem. 1993, 25, 621-630. [CrossRef]

29. Uchida, Y.; Clough, T.J.; Kelliher, F.M.; Sherlock, R.R. Effects of aggregate size, soil compaction, and bovine urine on $\mathrm{N}_{2} \mathrm{O}$ emissions from a pasture soil. Soil Biol. Biochem. 2008, 40, 924-931. [CrossRef]

30. Rasse, D.; Økland, I.; Bárcena, T.G.; Riley, H.; Martinsen, H.; Sturite, I.; Joner, E.; O’Toole, A.; Øpstad, S.; Cottis, T.; et al. Muligheter og Utfordringer for økt Karbonbinding i Jordbruksjord (Possibilities and Challenges for Increased Carbon Sequestration in Agricultural Soil, in Norwegian); Nibio Report 5 (36); 2019; 93p. Available online: https://www.landbruksdirektoratet.no/no/fou-midler/ jordbruks-og-matforskning/_attachment/74080?_ts=1699f22b208 (accessed on 10 February 2020).

31. Norwegian Environment Agency. Klimakur 2030-Tiltak og Virkemidler Mot 2030. (Climate Strategy to 2030), Report M1625. 2020. Available online: https:/ / www.miljodirektoratet.no/globalassets/publikasjoner/m1625/m1625.pdf (accessed on 10 February 2020).

32. Carson, R.; Groves, T. Incentive and informational properties of preference questions. Environ. Resour. Econ. 2007, 37, 181-210. [CrossRef]

33. Venkatachalam, L. The contingent valuation method: A review. Environ. Impact Assess. Rev. 2004, 24, 89-124. [CrossRef]

34. List, J.A.; Gallet, C. What experimental protocol influence disparities between actual and hypothetical stated values? Environ. Resour. Econ. 2001, 20, 241-254. [CrossRef]

35. Morgan, D.L. Focus Groups as Qualitative Research; Sage: Thousand Oaks, CA, USA, 1997.

36. Leiserowitz, A.; Maibach, E.; Rosenthal, S.; Kotcher, J.; Bergquist, P.; Ballew, M.T.; Goldberg, M.; Gustafson, A. Climate Change in the American Mind: November 2019. PsyArXiv 2020. [CrossRef]

37. CICERO. Klimaundersøkelsen 2018, (Climate Attitudes in Norway). 2018. Available online: https://cicero.oslo.no/no/ klimaundersokelsen-2018 (accessed on 4 June 2021).

38. CICERO. Et Dypdykk i Folket, (A Dive into People's Minds). 2019. Available online: https://cicero.oslo.no/no/posts/nyheter/ et-dypdykk-i-folket-vol-2 (accessed on 4 June 2021). 